\title{
利根川汽水域における 細粒底質の浮上現象について \\ STUDY ON THE SURFACING OF FINE SEDIMENT IN THE TONE RIVER ESTUARY
}

\author{
石川忠晴 1 ・松延和彦 2 ・箕浦靖久 3 ・佐々木努 4 \\ Tadaharu ISHIKAWA, Kazuhiko MATSUNOBU, Yasuhisa MINOURA and Tsutomu SASAKI

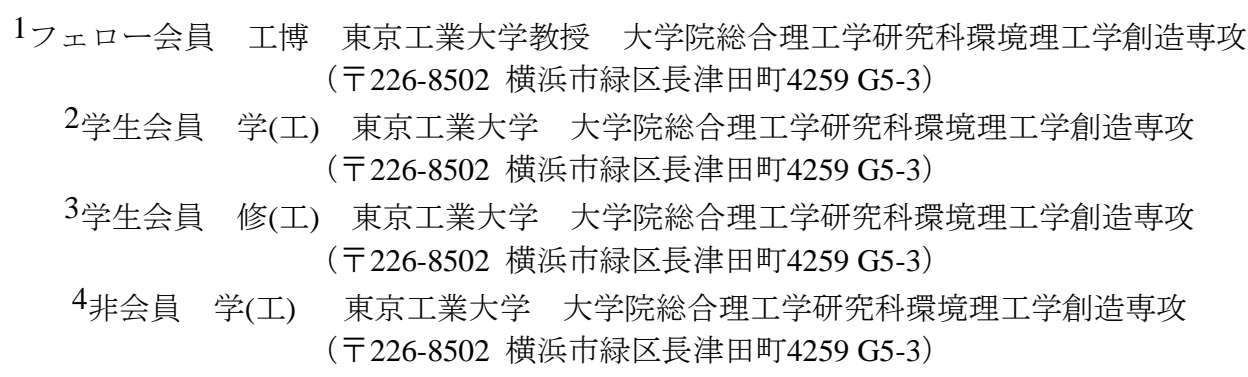

Fine bed sediment in a river estuary is sometimes flushed by a freshet, and it affects bio-chemical condition in the estuary. The process of the phenomenon has not been much clarified yet because of the difficulty of measurements. This paper discusses the phenomenon by paying attention to black patterns of the water surface appearing on aerial photos taken in the Tone River estuary during a freshet. Sediment data suggests that the patterns correspond to deoxidized fine sediment raised from the channel bed. From correlations of the patters with bed topography and flow field obtained from stereo analysis of the aerial photos, the process is considered as follows: A turbulent spot caused by a local depression of channel bed triggers sediment pick up and intensifies vertical mixing, raising the sediment to the water surface. The transverse shear between the vertically mixed zone and the surrounding flow generates further turbulence, resulting in the expansion of the zone of vertical mixing and sediment rising.

Key Words : River estuary, surfacing of fine sediment, aerial photo analysis, vertical mixing

\section{1. はじめに}

河川感潮域では塩分の影響により微細粒子がフロック を形成し沈降しやすくなる1). また堆積した粒子はエス チュアリ循環によって上流に輸送される め塩水層が停滞する区間の表層底質は細粒成分が支配的 となる. 細粒底質は有機物や被酸化物質および栄養塩類 を多く含むため，水環境に大きな影響を及ぼしている゙． 特に貧酸素水塊の形成は汽水生物に大きな打撃を与える ことがある7).

しかし汽水域の底質状態は出水によって大きく変化す $3^{8), 9)}$. 比較的大きな出水では細粒底質の層が消失して短 時間に粗粒化し，その後の塩水回帰によって細粒化が 徐々に進行する. 出水時における観測は容易でないため, 細粒化の過程に比較して粗粒化の過程は十分捉えられて
いない. 加えて粗粒成分に比べて細粒成分の運動則に関 する理論は未発達であり, 数值計算などによる研究も十 分行われていない状況にある.

本研究では，2001年9月の利根川出水時に撮影された 汽水域の航空写真から, 細粒成分の巻き上げ状況を推定 し考察を加える. この航空写真では，汽水域下流部の水 面に細粒底質の局所的浮上と思われる黒色の模様が捉え られている. そこで航空写真解析により流速分布, 流線 などを求め, 黒色模様との対応関係を調へ，細粒底質の 浮上メカニズムを考察した.

\section{2. 出水による底質の粗粒化}

\section{（1）対象河道の特性}

検討対象である利根川汽水域の平面形状を図-1-1に, 


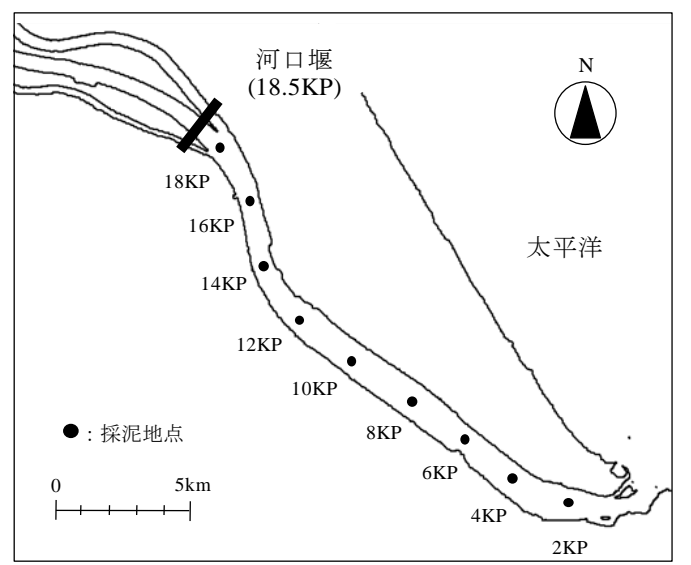

図-1-1 利根川汽水域の平面図

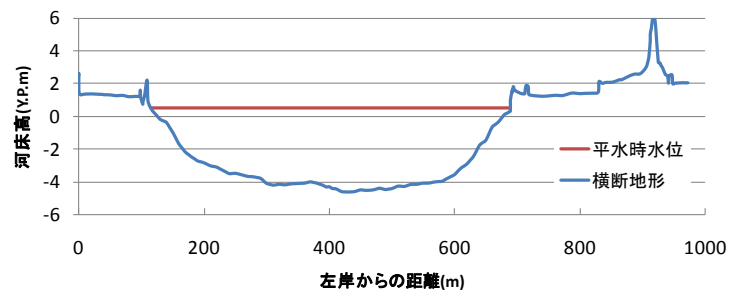

図-1-2１6KPにおける断面図

代表的な断面形状を図-1-2に示す．利根川汽水域は延長 約 $18.5 \mathrm{~km}$ で，緩やかな湾曲部を有寸るが概ね直線的な河 道で，河床はほぼ水平 $(1 / 10,000$ 程度) である。堤防法 線間隔は約 $900 \mathrm{~m}$ ，低水路幅は約 $600 \mathrm{~m}$ で，平常時の低水 路水深は $5 \mathrm{~m}$ 程度である.

平常時には潮汐に伴う流動が支配的である．ただし 18.5Kにある河口堰から潮位変動に同期した放流が行わ れるため, 自然の潮汐流動之は異なり, 塩水楔の移動量 は少なく, エスチュアリ循環が発達している7)。流量が $250 \mathrm{~m}^{3} / \mathrm{s}$ を超えると河口堰は全開となる.

\section{（2）底質粒度特性}

小林ら ${ }^{10}$ は, 利根川汽水域の多数の底質試料の粒度解 析を行い，宇野ら ${ }^{11)}$ の方法を用いて利根川汽水域の底質 データを整理した．その結果，(1)底質は式(1)で示す4つ の対数正規分布の和で表わされること，(2)それらのうち 細粒の2つの成分は常にほぼ同じ比率で一緒に現れるの で一つのグループとみなせること, (3)したがって流況変 化に伴う底質粒度変化は3成分の配分によって説明でき ることを示した. 各成分の平均粒径および標準偏差を表 -1 に示す.

$$
f(D) d D=\sum_{i=1}^{N} \alpha_{i} \frac{1}{s_{i} \sqrt{2 \pi}} \exp \left\{-\frac{\left(X-X_{i}\right)^{2}}{2 s_{i}{ }^{2}}\right\} d X
$$

ここに $\quad X=\log D, \quad X_{i}=\log D_{i}, \quad s_{i}=\log \sigma_{i}$ である

$D_{i}, \sigma_{i}, \alpha_{i}$ はそれぞれ第 $i$ 成分のモード径，幾何標準偏差， 成分割合であり，最小二乗法を用いて決定される.
表-1 各成分の平均粒径と標準偏差

\begin{tabular}{|l|l|l|l|}
\hline \multicolumn{2}{|c|}{ 成分名 } & $\begin{array}{l}\text { 平 均 粒 径 } \\
{[\mu \mathrm{m}]}\end{array}$ & $\begin{array}{l}\text { 標 準 偏 差 } \\
{[\mu \mathrm{m}]}\end{array}$ \\
\hline \multirow{2}{*}{\begin{tabular}{|} 
シルト \\
[ 第一成分 $(75 \%)$
\end{tabular}} & 7.9 & 3.3 \\
\cline { 2 - 4 } & 第二成分 $(25 \%)$ & 36.2 & 1.8 \\
\hline \multicolumn{2}{|l|}{ 細砂 } & 100.0 & 1.7 \\
\hline \multicolumn{2}{|l}{ 粗砂 } & 200.0 & 1.5 \\
\hline
\end{tabular}
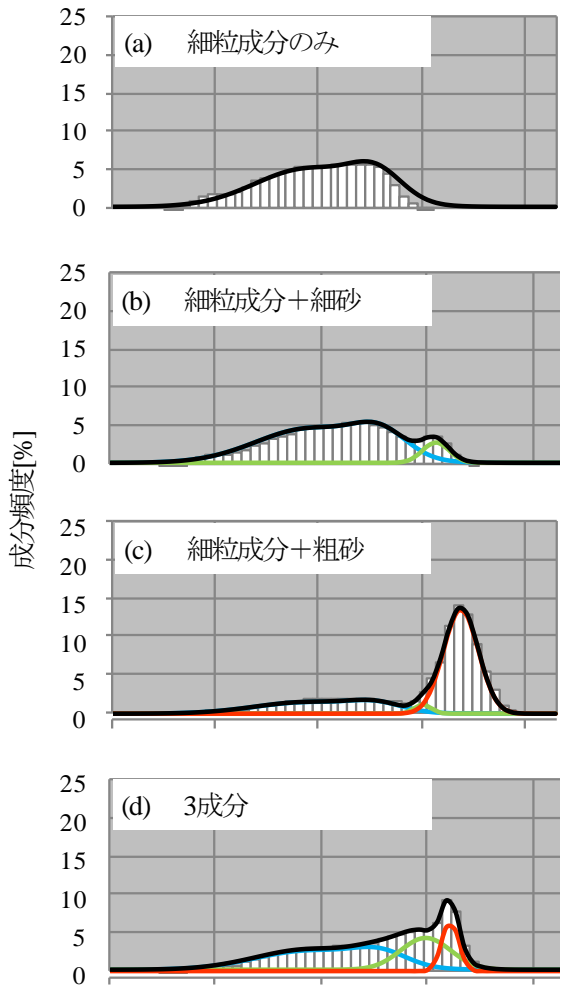

$\begin{array}{lllll}0.1 & 1 & 10 & 100 & 1000\end{array}$ 粒径 $[\mu \mathrm{m}]$ 一: シルトー: 細砂 一: 粗砂一: 近似曲線

図-2 粒度分布之解析結果

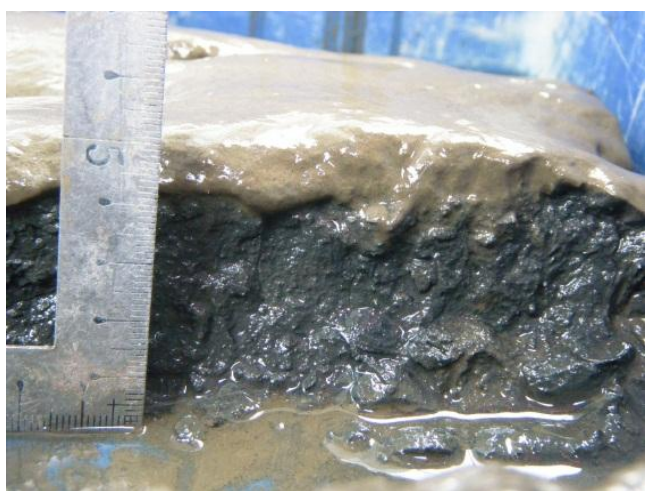

図-3＼cjkstart細粒底質の写真

図-2に底質粒度分布と上記の式で成分分解した結果を 示す．本論文で対象とする細粒底質は $1 \sim 80 \mu \mathrm{m}$ の広い粒 度を持つ成分で，主体はシルトである. 図-3に河床から 採取した細粒底質の写真を示寸.ごく表層の数mmを除 くと嫌気化して黒色を呈している. 


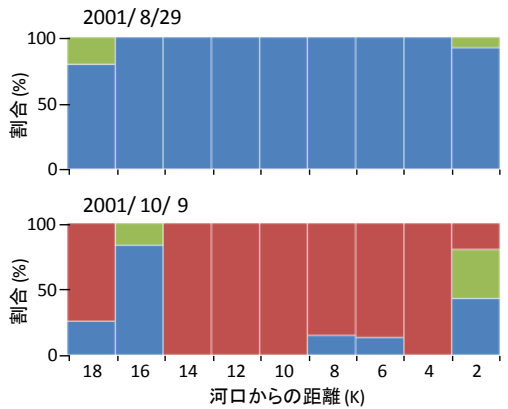

(a) 2001 年9月出水前後

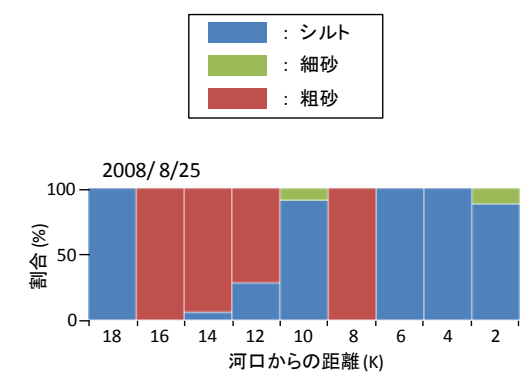

(b) 2008年小規模出水後
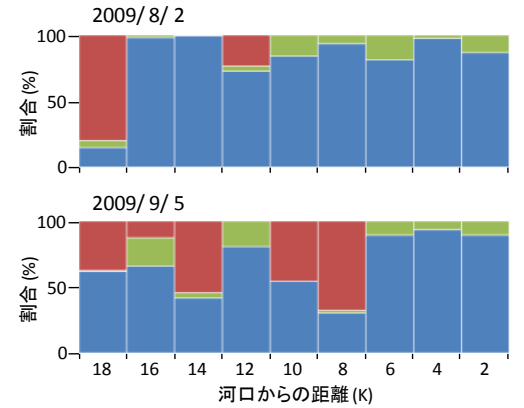

(c) 2009 年8月出水前後

図-4＼cjkstart出水前後における粒子構成割合の変化
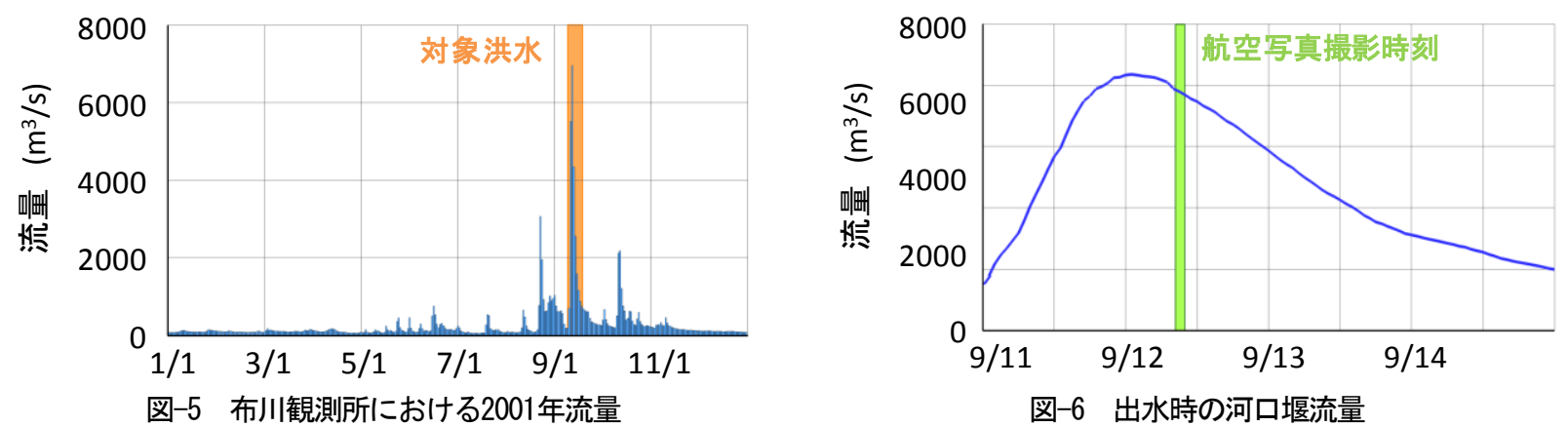

図-6 出水時の河口堰流量

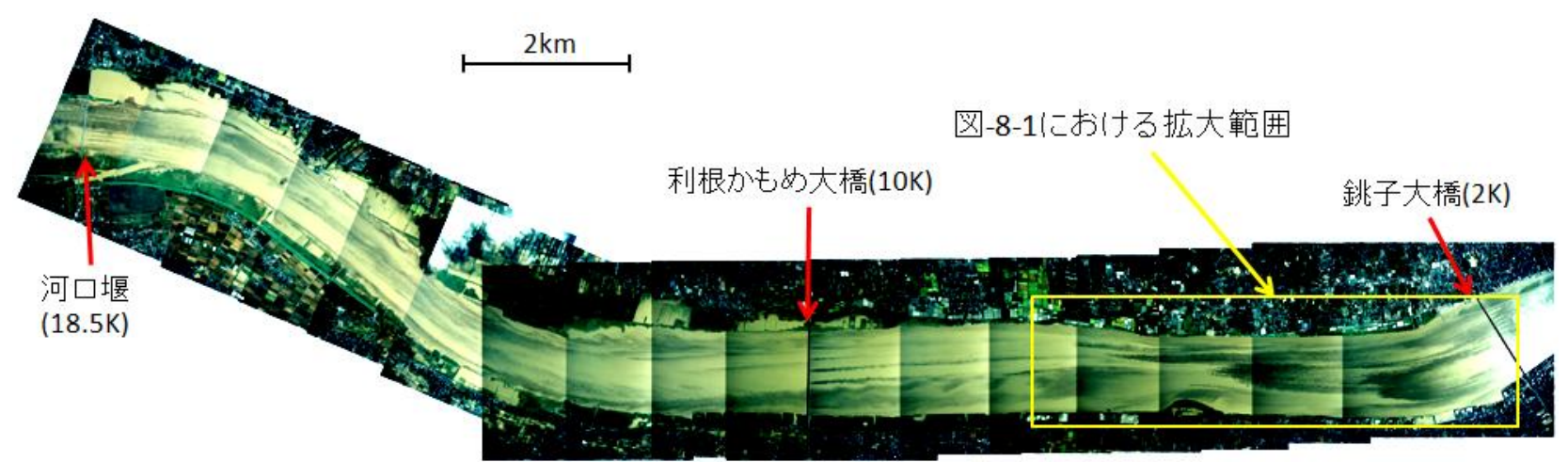

図-7 対象河道の洪水航空写真

\section{（3）出水時の粗粒化}

鈴木ら ${ }^{8)}$ は2001年8月から2002年2月にかけて，利根川 汽水域において底質調查を実施し，2001年9月12日出水 に伴う粗粒化と，その後の細粒化の経過を報告している. 鈴木らのデータを小林ら ${ }^{10}$ が再整理して前述の 3 成分の 配分比を求めた結果を図-4(a)に示寸．また最近行われ た底質調查のうち，2008年8月と2009年8月11日出水の前 後の調査の結果を図-4(b) および図-4（c) に示す，なお， 2008年には6,7月に $500 \sim 1000 \mathrm{~m}^{3} / \mathrm{s}$ の小出水が度々生じて いたが，その間の調査データはない. 2001年9月出水と 2009年8月出水のピーク流量はいずれも当該年の最大流 量であり, 最近 20 年の年最大流量の中で 2001 年出水 $\left(7,813 \mathrm{~m}^{3} / \mathrm{s}\right)$ は第2位， 2009 年出水 $\left(2,759 \mathrm{~m}^{3} / \mathrm{s}\right)$ は第 11 位で あった。

2001年出水後の調查（10月9日）は出水からやや時間 が経っていたため部分的に細粒分が現れているが，出水 直後には汽水域の大部分が粗粒化していたものと考えら
れる.これに対して2009年出水では粗粒化は上中流部に 限られている. また2008年のたびたびの小出水後の粗粒 化も上中流域に限られている. このことから, 出水によ る底質の粗粒化は上流側から始まるのではないかと思わ れる.下流部の底質は塩水に接する機会が多いので, 細 粒分の堆積厚が大きいか固結度に違いのある可能性があ る. あるいは地形的な要因で局所的に上中流部の掃流力 が大きいことなども考えられる.

\section{3. 洪水航空写真解析}

\section{(1) 浮上した細粒底質が作る水面模様}

2001年出水を含む期間の布川流量時系列を図-5に，利 根川河口堰で推定された出水時の流量時系列を航空写真 撮影時刻とともに図-6に示す．撮影は洪水ピークの10時 間後に行われた。一般に掃流力のピークは洪水流量のピ 


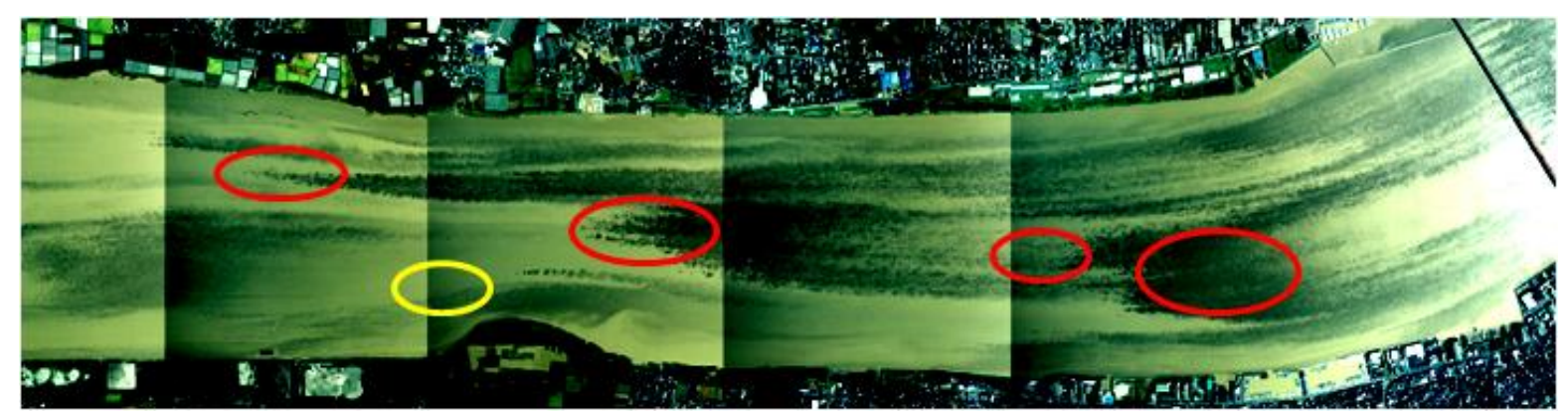

図-8-1 8-2Kの航空写真

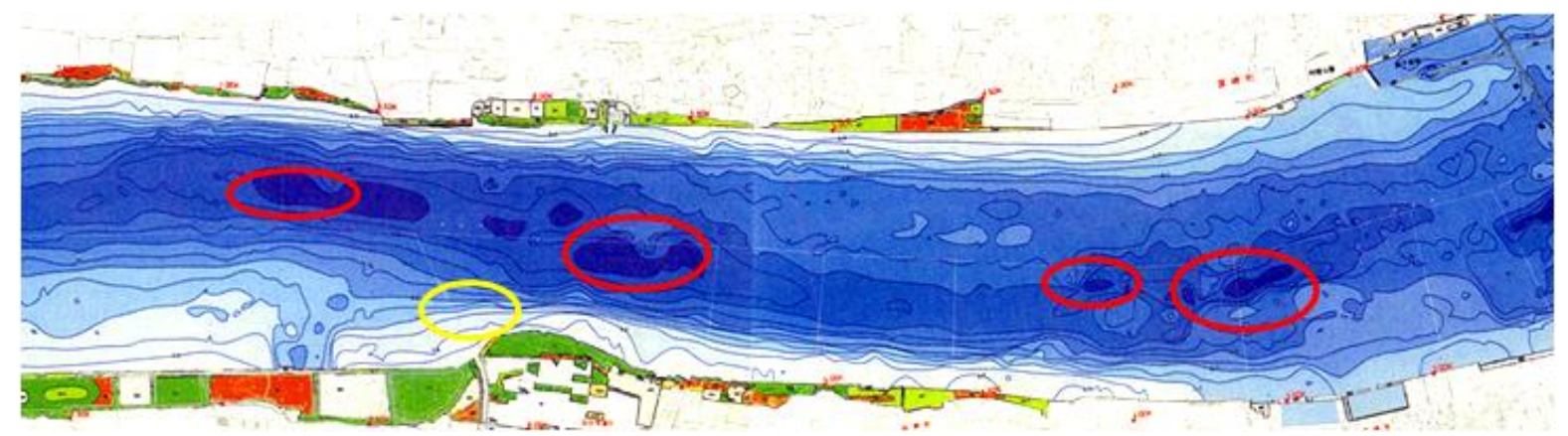

図-8-2 航空写真に二対応する地形

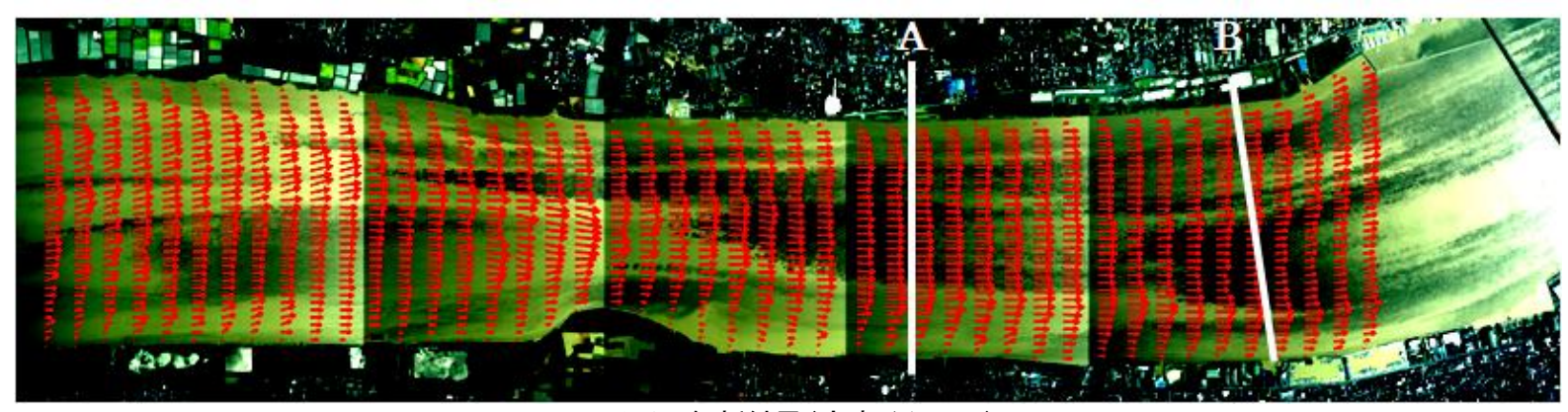

図-9-1 解析結果(流速ベクトル)

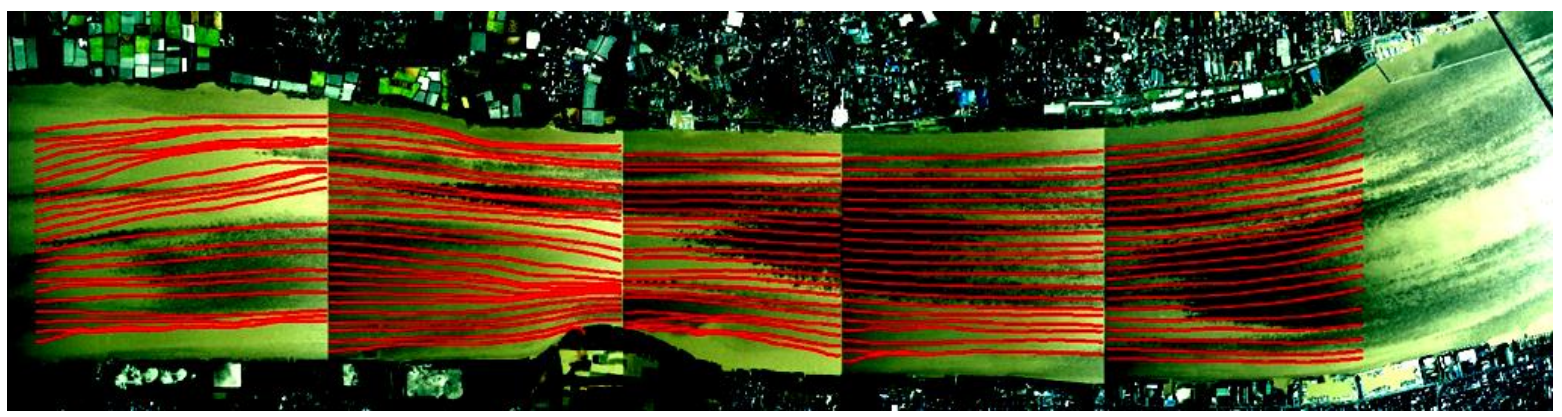

図-9-2 解析結果(流線)

一ク以前に生じるので，写真撮影の時刻は河床洗掘の最 盛期を過ぎていたと考えられる.

洪水航空写真を合成して図-7に示寸，黒色の濃淡が随 所に見られるが，特に10Kの利根かもめ大橋の下流側と $7 \mathrm{~K}$ 以降で濃くなっている。これらは細粒底質が水面に 浮上した結果であると考えられる．前者は橋脚の位置に 対応していることから, 橋脚背後の馬蹄形渦により巻き 上げられたものと考えられる。一方下流部の巻き上げ部 分には人工構造物は存在せず，河床地形に関係している 可能性がある. そこで図-8-1と図-8-2に下流部の航空写
真と地形図を拡大して示す。黒色の水面模様は “いくつ かのポイント”から発生し，下流に向かって拡大してい る. そのポイントの多くは，赤色の棈円でマークしてい るように，地形図上の深掘れに対応しているように見え る.すなわち細粒底質の巻き上げは，河道全体で同時に 発生するのではない，このことから，河道平均的な掃流 力よりも, 局所的な地形により発生寸る乱れの増大が引 き金となって生じるのではないかと考えられる，実際， 深掘れ部分では強い乱れと上昇流が発生することが知ら れている ${ }^{12)}$. なお黄色の楕円については（2)で述べる. 

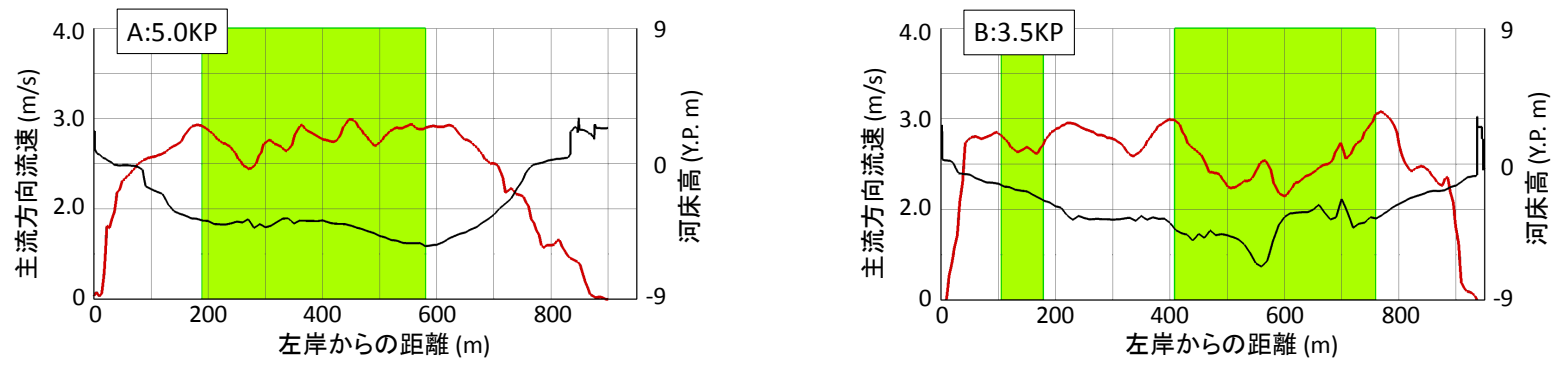

図-10 断面形と流速横断分布

\section{(2) 航空写真解析結果および考察}

航空写真解析は箕浦ら ${ }^{13)}$ の方法を用いた. 飛行方向(x) とそれに直交する方向(y)に等間隔の矩形格子を設定し画 像相関法を適用寸る，その際，画像ピクセルごとの相関 係数をCIP内挿し三次精度で流速べクトルを求める.た だし画像相関法は画像濃淡の薄い部分などで正しい結果 を得られないこともあるので，さらにステレオ画像上で 解析者が過誤を直接修正する. 作成された矩形格子上の 流速データをさらにCIP内挿し, ルンゲクッタ法により 流線方程式を積分し流線図を作成した．図-9-1に流速心゙ クトル図を，図-9-2に流線図を航空写真に重ねて示す. なお流線は写真ごとに求めているので連続してはいない. 水面の黑色の特に濃い2断面A,Bについて, 流速横断分布 を横断地形図とともに図-10に示寸．図中の緑色の網掛 けは，航空写真で黒く見える部分を示している．この部 分の流速が周囲より減少していることから，底層水の “湧昇”または底層水之表層水の “鉛直混合” が生じ, それに伴い細粒底質が水面に浮上したものと考えられる. 底層水の湧昇は河道湾曲による二次流や並列螺旋流あ るいは橋脚などの構造物に伴い生じることが多い，その 場合は図-11の断面内流れの概念図に示寸ように，下層 水が表層水を押しのけて表層に広がる. したがって, 湧 昇によって運ばれた細粒底質の外縁は表層流線と概略一 致することになる.しかし図-9-2に示した表層流線は， 黒色域が拡大寸る部分では一致していない.このことか ら湧昇流は明確には存在せず，鉛直混合によって底質が 表層に運ばれているものと推察される.

一般に河床の凹部で乱れが増加し鉛直混合が発生しや すい ${ }^{12)}$. 図-8-1 と図-8-2の赤色の楕円の対応はこの現象 を表していると考えられる。.また浅い領域から深い領域 に流線が斜めに侵入する場合にも同様の力学的効果が生 じるものと推測される. 図-8-1と図-8-2の黄色の楕円は, 図-9-2の流線図をもとに該当寸る部分を示したものであ る. この部分でも水面が黒色になっていることがわかる.

\section{(3) 細粒底質浮上のメカニズム}

以上の知見をもとに, 利根川汽水域下流部での細粒底 質浮上の概念モデルを以下のように考えた.

シルトを主体とする細粒底質は有機物などを含み，ま

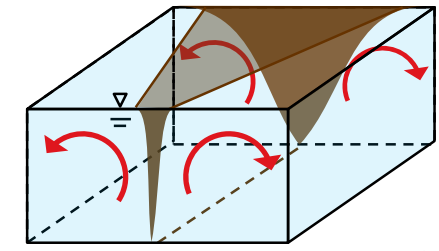

図-11 2次流による底質巻き上げ

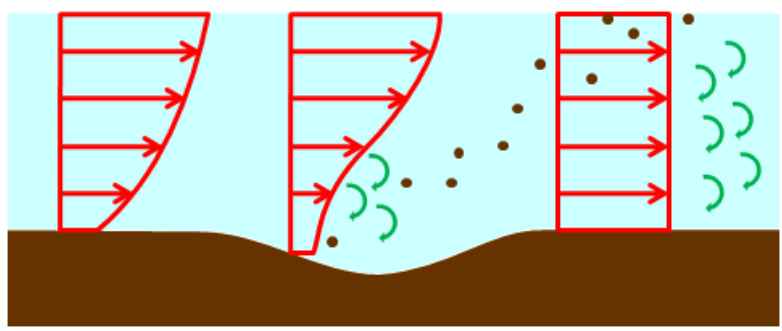

（a） 河床凹部前後での鉛直流速分布の変化

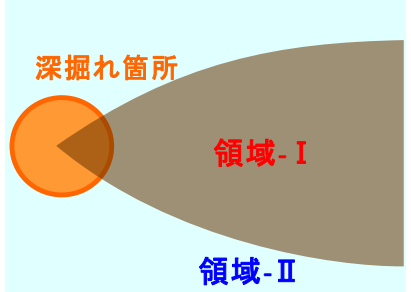

(b) 領域の設定

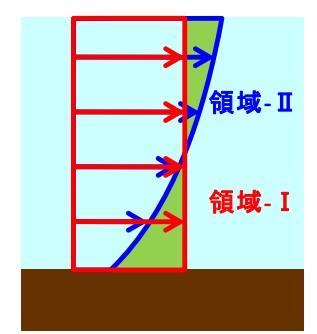

(c) 領域 I， IIでの流速
図-12 鉛直混合の概念モデル

た電気的性質も持つ.このため砂などの粗粒底質と異な り, 河床に堆積後には粘着性ないし固結性が増加してく る. 実際，採泥した底質は，図-3に示したように採取後 も形が崩れない，その結果, 出水時に発生する大きな掃 流力でも容易には巻きあがらない可能性がある.

しかし河床面に凹凸がある場合，図-12 (a)に示すよう に, 下り斜面で流速鉛直分布に変曲点が生じ, 乱れが増 加しやすい. この局所的乱れの増加により河床から細粒 底質が巻きあがる可能性がある．また局所的な鉛直混合 の増大により流速が上下方向に一様化するとともに, 巻 きあがった底質が上方に輸送される，河床の凹部で鉛直 混合が進み流速が一様化した部分を領域- I , その外側 を領域-II とする(図-12(b))。底層付近では領域- I での 流れが速く, 表層付近では領域-IIでの流れが速い（図12(c)）。したがって両領域の境界付近では横断方向の せん断が発生し, 鉛直混合の強い領域が領域- II に向 かって広がっていくものと考えられる. 


\section{4. おわりに}

本研究では，利根川汽水域下流部における出水時の細 粒底質巻き上げの機構について，2001年9月出水時の航 空写真をもとに考察した. その結果を以下に要約する.

・ 細粒底質の巻き上げは，河床が窪んでいる箇所から 発生し，両側に拡大していく。したがって，着目し た現象の発生は局所的条件に規定されている.

- 巻き上げ領域拡大部の外縁線は流線と一致しないこ とから，底質の巻き上げは螺旋流的運動によるので はなく，窪地での乱れ増大に起因する鉛直混合に依 存していると考えられる.

・ 巻き上げ領域外縁では横断方向のせん断により乱れ が発生し，その結果として，乱れ領域の両側への拡 大が生じ，巻き上げが側方に伝播していく.

以上は，現段階ではあくまで推測であり，今後確認し ていかねばならない要素を多々含んでいる。しかしなが ら，航空写真に現れた現象は，“掃流力分布に従って Pick upされる” という従来の粗粒成分に対する流砂現象 の考え方では理解しにくい面が多く, 議論を喚起すると いう点を重視して報告させていただいた。

謝辞 : 本研究の実施にあたり，国土交通省関東地方整備 局利根川下流河川事務所から種々の助力をいただいた. また本研究は科学研究費（基盤研究(B)：20360217）お よび河川整備基金（20-1151-001）の補助を受けている. 記して謝意を表する.

\section{参考文献}

1）山下俊彦・森田真郷・杉原幸樹 - 斎藤大作・山崎真一 : 石狩川河川水中の䀣濁粒子の海水混合による凝集過程に 関する研究, 海岸工学論文集第 49 巻, pp.1016-1020, 2002.

2) Postma,H. : Sediment transport and sedimentation in the estuarine environment, In estuaries, AAAS Publication, No.83, pp.158-179, 1967.
3) Festa J.F. and Hansen D.V. : Turbidity maxima in partially mixed estuaries : a two-dimensional numerical model, Estuarine and Coastal Marine Science, 7, pp.347-359, 1978.

4) 鈴木伴征 - Arthur SIMANJUNTAK - 石川忠晴 - Jorg IMBERGER・横山勝英 : 利根川河口堰下流部における潮 汐流動に伴う微細粒子の運動, 水工学論文集第 48 巻, pp.775-780, 2004.

5）八木宏・大森義暢・高橋亜依 : 多摩川河口域における流 れと懸濁物質輸送特性について, 海岸工学論文集第 50 巻, pp.461-465, 2003.

6) 例えば，山内克典 : 長良川河口堰が底質と二枚貝に与え た影響, 応用生態工学 5(1), pp.53-71, 2002.

7) T.Ishikawa, T.Suzuki, X.Qian : Hydraulic Study of the Onset of Hypoxia in the Tone River Estuary, Journal of Environmental Engineering Volume 130, Issue 5, pp. 551-561, 2004.

8) 鈴木伴征・大作和弘・石川忠晴 : 洪水に伴う利根川感潮 域の底質変化，河川技術論文集第9巻, pp.265-268, 2003.

9) 川西澄・筒井孝典・ 中村智史 - 西牧均 : 太田川放水路に おける土砂動態と底質変動, 海岸工学論文集第 52 巻, pp.906-910,2005.

10）小林侑・佐々木努 - 石川忠晴・箕浦靖久 : 利根川感潮域 における底質特性の季節变動について，水工学論文集第 54 巻, pp.679-684,2010.

11）宇野宏司・中野晋・亘隆史 : 四国周辺の干潟における稀 少種「シオマネキ」の生息地適性評価, 海洋開発論文集 第 18 巻, pp.185-190,2002.

12）禰津家久・門田章宏・新橋秀樹 - 倉田昌明 : 河床波上非 定常開水路流れの時空間相関構造に関する研究，土木学 会論文集 No.579/II-41，pp.125-136,1997.

13）箕浦靖久 - 石川忠晴 - 吉田圭介 : 実体視と相互相関解析 を併用した洪水航空写真解析手法の構築と検証, 水工学 論文集第53巻, pp.997-100,2009.

(2010. 9. 30受付) 